\title{
Zdenko Čepič
}

\section{The Student Movement 1968/1971 in Ljubljana in Wider Context}

Ev'rywhere I hear the sound of marching, charging feet, boy 'Cause summer's here and the time is right for fighting in the street, boy

Well then what can a poor boy do Except to sing for a rock ' $n$ ' roll band 'Cause in sleepy London town There's just no place for a street fighting man No! (Street Fighting Man, The Rolling Stones (M. Jagger, K. Richards), 1968 ${ }^{1}$ !)

\section{IZVLEČEK}

\section{ŠTUDENTSKO GIBANJE V LJUBLJANI 1968 IN 1971 V ŠIRŠEM KONTEKSTU}

Vletu 1968 so bili med političnimi dogodki tega leta (»Praška pomlad « in njen konec, predsedniške volitve $v$ ZDA, protesti proti vojni $v$ Vietnamu, ... ) pomembni študentski protesti. Bili so po vsej Evropi, najbolj intenzivni v Parizu. Bili so tudi v Jugoslaviji, v Beogradu (začetekjunija). VLjubljani so bili študenti v svojih protestih bolj socialno usmerjeni kot pa

\section{* Research Counsellor, PhD, Institute of Contemporary History, Kongresni trg 1, SI-1000 Ljubljana, Slovenia,} zdenko.cepic@inz.si

1 The song was created under the impression of student protests in Paris. The words of the song Mick Jagger wrote in spring of 1968 and published in the review The Black Dwarf, political and cultural newspaper (published between May 1968 and 1972) by a collective of socialists in United Kingdom (editor was Tariq Ali, British Pakistan writer, journalist, historian, filmmaker, political activist). Jagger wrote the song after he attended a 1968 anti-war rally at London's US embassy. He also found inspiration in the rising violence among student rioters in Paris. The author of the song Mick Jagger remembered: "It was very strange time in France. But not only in France but also in America, because of the Vietnam War and the endless disruptions... I wrote a lot of the melody and all the words." This song originally titled and recorded as "Did Everyone Pay Their Dues?" containing the same music but very different lyrics. The song became well known in August 1968 (single); in December 1968 it appeared in album Beggar's Banquet. "Street Fighting Man" is the band's most political song. The song was released within a week of the violent confrontations between the police and anti-Vietnam War protesters at the 1968 Democratic National Convention in Chicago. Worried about the possibility of the song inciting further violence, Chicago radio stations refused to play the song. 
politično. Več političnega je bilo v protestih študentov $v$ Ljubljani aprila in maja 1971, ko so iz protesta zasedli Filozofsko fakulteto. Avtor na osnovi dokumentov slovenskega študentskega gibanja prestavlja delovanje študentov v Ljubljani leta 1968 in 1971.

Ključne besede: študentsko gibanje, študentski protesti, politika, Jugoslavija, Slovenija, Univerza $v$ Ljubljani

ABSTRACT

In 1968, during the political events of this year (»Prague Spring « and its end, US presidential elections, protests against the war in Vietnam,...) significant student protests took place. They were all over Europe, the most intense in Paris. They were also in Yugoslavia, in Belgrade (early June). In Ljubljana, students in their protests were more socially oriented than political. More political occurred in students' protests in Ljubljana in April and May 1971, when the Faculty of Arts students took over for eight days. The author presents the work of students in Ljubljana in 1968 and 1971 on the basis of the documents of the Slovenian student movement.

Keywords: student movements, students protests, politics, Yugoslavia, Slovenia, University of Ljubljana

The student movement is "a specific phenomenon of a relatively mass protest on the world scale, related to the tradition of proletarian movement for citizen's rights and to the tradition of war and post-war intellectual movements." One can speak of the student movement as a historical phenomenon in particular in the late 1960s, when it was an organised political activity of students aimed at achieving certain political goals. Mass student movements were a characteristic of the late 1960s throughout the world. Although student protests started even before 1968 - at some universities in the USA, first at Berkeley where students protested against the war in Vietnam - the worldwide student unrest actually culminated in 1968. It, however, continued also after that year. In Slovenia it climaxed three years later.

The active and mass student movement of the late 1960s was on the one side marked by its world dimension stemming from similar social and economic issues, and on the other side movements in individual countries had certain specific features. They were reflected in diverse forms of protests as well as in the very causes for opposition and the goals which they wanted to achieve. The political demands of students varied across the countries. In the USA, they called for the end of war in Vietnam, in France

2 Darko Štrajn, “Nekoč je bilo študentsko gibanje?," in: Pričevanja, December 1985: študentske pomladi, eds. Iztok Ilich et al. (Ljubljana: Partizanska knjiga, 1986), 183, 184. 
they fought against the authoritarian De Gaulle regime, in the "real socialism" countries they aspired for greater democratisation against the state bureaucracy, whilst in Yugoslavia they demanded greater consistency of the socialist self-management system.

The student movement - given the lack of any formal connectedness (organisational or substantive) between the students' activities in various countries - were largely political. The causes were in the first place social and the movements were a response of students to the current social conflicts. They emerged as a critical "conscience" of economic and social relations and the contradictions in the society. They had ideological roots in Marxism and had a character of a "new leftist" movement. This was the case in western as well as eastern student movements. In Yugoslavia, students advocated socialism, but they wanted to make it better, more humane. What was common to all student movements was their anti-war, pacifist orientation enshrined in a slogan "Make love, not war". Their political goals were aimed at changing the society towards greater democratisation and humanisation. Students wanted to save the world and change the social conditions. They were agitated by the social relations that were established by developing capitalism and contributed to increasing social disparities. Capital and consumerism brought the working classes to apathy, and the students considered themselves the chosen ones to draw attention to social problems. They wanted not only to explain the world, but to change it. Their intention was to "revolutionise the every day life". Above all, the student movements were aimed at establishing students as a political subject of a society.

The student movement marked a certain historical period and was aimed at solving not only the problems of that period and but also more long-term ones. All student actions had a common purpose - social "purification". As a consequence of the increasing social disparities in the capitalist world, and also in Yugoslavia, the students in the developed countries of the West expressed their demands for greater social justice. In the Eastern European countries of the Soviet political reality, however, the demands for political changes or at least political "loosening" were in the forefront.

Common to all students' political activities in the late 1960s was the question against whom and against what their activities were oriented, what were their motives and reasons for action. They also shared their eruptive character, dynamism, radical views and goals. Each movement emerged from its own environment, from the critical attitude towards it, from the criticism of university system and the demands for reforms of the study process. At this stage, they wanted to become a subject or better, a partner in the reform of the university and study. This "mobilisation" phase was followed by a phase that went beyond the university and student problems, questioning wider social issues. The student movement turned into a political movement, and students wanted to become an important social subject capable of changing the world. They saw themselves as the essence of social change, as a substitute for the former revolutionary workers' movement.

There were similarities and also great differences between student movements in the world, in Europe and even in Yugoslavia, where it evolved differently in various 
university centres. It was the same and very different at the same time. Students were solving global problems on a local scale, as the movements in individual countries, including Yugoslavia, stemmed from diverse political, economic and social conditions. The methods of showing disapproval with the situation at universities and in the society were more or less the same everywhere, but the demands and goals varied. The student movement in Yugoslavia and Slovenia differed from that in the Western and Eastern Europe, as it did not reject the existing political system. It supported and approved it, but demanded greater consistency in its implementing. It supported the self-management socialism and considered it the best possible political system.

The student movement in Yugoslavia and Slovenia arouse from the social and political reality of the 1960s. The outbreak in 1968 coincided with political, economic and social conditions emerging from the crisis of economic reform. The problems typical for a consumer society, to which Yugoslavia was entering at that time, came out, such as increasing social disparities, increasing wealth of selected individuals, difficulties in finding employment, looking for work abroad. In the political arena, this was a period of conflict between those in favour of greater centralisation and those in favour of de-centralisation and greater role of national entities - republics, and liberalisation of political and economic relations. The reform in the mid-1960s was meant to provide the economy a great momentum, but had many social consequences, i.e. consumerism, individuals gaining wealth usually in suspicious ways, social differentiation; all of these affected also students. In their public appearances in 1968, they clearly condemned these deviations and required "corrections". They wanted to establish an ideal system.

$* * *$

The student movement in Europe is closely connected with the year 1968. Not only in European but also in the Yugoslav history, this year has a special significance. It was a turning point in many aspects. There were a number of events which shook the Yugoslav political reality, in particular the Yugoslav political leaders, who had to start searching for different solutions to the pressing problems. The student demonstrations in Belgrade in early June 1968 caused the first serious political uproar. "The Prague Spring" - an attempt of the new leadership to bring more democracy to the social system was also felt in Yugoslavia. The Yugoslav political leaders approved of the events in the Czechoslovakia and during his visit to Moscow in April 1968, Tito tried to dissuade his counterpart Brežnjev from interfering in the Czechoslovak internal affairs. When Brežnjev decided for an armed "defence" of socialism and sent the armed forces of five Warsaw Pact countries to Czechoslovakia on 21 August 1968, the Yugoslav party leadership condemned the intervention and believed it was in fact a demonstration of power to Yugoslavia. ${ }^{3}$

3 Jože Pirjevec, Jugoslavija 1918-1992: nastanek, razvoj ter razpad Karadjordjevićeve in Titove Jugoslavije (Koper: Lipa, 1995), 276. 
In 1968, Slovenia and Yugoslavia entered the phase of "core liberalism". The "party liberalism", which was supposed to change the manner of operation within the party and also within the state and its system, ${ }^{5}$ marked the politics in the following years, up to its ending in 1972. The emergence and the end of the student movement and the "party liberalism" thus roughly coincided. Like "liberalism", also student movement was swept away by the storm of "pseudo-revolution", which after 1972 spread all over the Yugoslav society and was manifested in the overall "proletarization".

It is difficult to decide where to place the student movement in the political struggle between the "liberal" and the "conservative" political poles. Their demands for greater efficiency of the socialist self -management political system were close to the "conservative" beliefs. "Conservatives" controlled the leadership of the party (the Union of Communists of Slovenia), whereas the party "liberals" were concentrated in the government. Although students chose the state authority as their main "adversary", they were also very critical to the rigid party leadership. They were aware that it was the party that was behind the government and that it was not ready to change. Students supported the socialist self-management system, but they required the changes that would make it more efficient, democratic and humane. ${ }^{6}$

The student movement in Ljubljana was thus on the one side an expression of anticapitalist views, and on the other side a criticism of communist power in Yugoslavia. Students in fact fought for communism against "communism".

$* * *$

Most student protests in the world sparked off in 1968. Everywhere they happened suddenly and spontaneously. The reasons behind them varied. Although usually the eventual reason for a student revolt was rather banal, marginal, the real causes became clearer later. The problems which at first seemed marginal turned to be crucial. Although it all started in Germany at the beginning of the year, Paris soon became the epicentre of the student unrest in Europe, witnessing heavy student protests. Barricades were erected. Students were supported by workers' general strike, which caused a chaos in France and put at risk the authority of General De Gaulle. Student protests started also in the Eastern European countries and in Yugoslavia. They were not mere imitations of protests in the capitalist countries, because they had different reasons and demands. In Prague, student protests were sparked off by poor living conditions, but soon also demands for democratisation were expressed, thus supporting

4 Božo Repe, "Liberalizem" v Sloveniji (Ljubljana: RO ZZB NOV Slovenije, 1992), 67.

5 The "liberals" wanted to change the manner of governing, but not the political system: socialism and self-management. They advocated the "correction" of the Yugoslav socialism, in particular in the economy; as for the political relations, they emphasised the need for rearranging the relations in the federative state, notably between the "centre" and the republics.

6 See "programme” of May 1970, Tribuna, Nov. 1970. "Revolucioniranje družbe in univerze," in: Ciril Baškovič et al., Študentsko gibanje: 1968-72 (Ljubljana: Republiška konferenca ZSMS, Univerzitetna konferenca ZSMS, 1982), 77-80. 
the views of the "Prague Spring". In Poland, the authorities set the workers against the students.

In Belgrade, the student unrests started in early June 1968. The reason was truly banal: they could not agree who would occupy more sits to watch some show, students or brigadiers. After the fight broke out, the police intervened with force. This led to a student uprising. Students were exasperated at the brutality and relentlessness of the police, who prevented them to march from the campus to the city centre. At first, students had no programme or specific goals. These were only formulated after the fight with the police, as police represented the authorities. They formulated their political and social demands and addressed them to the authorities. They protested against the inconsistencies of the Yugoslav society, but mostly from the perspective of the situation in Serbia and Belgrade. They called for more consistency in functioning of the socialist self-management system, for less social inequalities, in short, they demanded a better socialism. A few days after the protests, the president of the state and the party Tito commented it on the TV. ${ }^{7}$ In principle, he supported the students and this was the sole example in the world that the president of the state and the governing party supported the demands of the students. He also said that if he was not capable of solving the problems expressed by the students, he could no longer stay on his present position. On the other hand, he was also a little insulted, as given the scope of these protests Yugoslavia lost the status of being a non-conflict state. ${ }^{8}$

Also in Slovenia (in Ljubljana, at that time the only Slovene university) the student movement as a political subject emerged for the first time in 1968. On 6 June 1968 students organised a protest meeting in the student campus, because the management of the campus decided to let student rooms to tourists during the summer, which is why students had to vacate them. At the same time, the management also announced to raise the prices of rents. This led to the beginning of organised students' movement at the Ljubljana University. Although these reasons seem banal, there were in fact deeper motives behind them, with a social connotation. The students expressed social demands, such as "Also students from poor families should study, not only those from wealthy families". They demanded greater role of students in managing the university, and they also reacted to the pressing social issues, such as gaining of wealth in dishonest ways, experts leaving the country to work abroad. ${ }^{9}$ One of the positions of the students was: "We want to use our knowledge at home". ${ }^{10}$ Around 3000 students participated in the protests, and even representatives of Slovene government. The government expressed its readiness to listen to the students. It obviously feared the

7 Baškovič et. al., Študentsko gibanje 68-72, 36. It is a collection of 227 documents, notably articles published in the student magazine Tribuna in the period 1968-1972.

8 SI AS 1589, Stenografske beleške sa IX. zajedničke sednice Predsedništva in Izvršnog komitete CK SKJ, održane 9. VI. $1968,77$.

9 Students largely opposed to the experts leaving the country to work abroad - the "gastarbajterstvo", which was very common in Yugoslavia after the economic reform in 1965. State employment services arranged the work abroad. In the period 1964-1969, 62,347 persons went to work to the Western-European countries through the state employment offices.

10 Baškovič et. al., Študentsko gibanje 68-72, 18, 19. 
protests to get out of control. Despite the concurrence of the protests in Ljubljana and Belgrade, there was no connection between the two. The demands were nevertheless similar, e.g. unfair gaining of wealth. Student in Ljubljana only found out about the protests in Belgrade through private channels, i.e. letters from their friends in Belgrade.

Also the student movement in Slovenia went through different phases, from the "trade unionist" demands stemming from worsening of students' material conditions to political demands. The political demands of students did, however, not go beyond the critical attitude to social discrimination and requests for social justice. In the following years however, the movement at the Ljubljana University became more radical and also political. It turned into a true student movement in terms of their demands and methods of work. This could largely be attributed to the students of social sciences, who by then took over the initiative of the student movement.

In 1969 and 1970, the student movement in Ljubljana focused their criticism to the foreign policy area and since 1970, they decisively intervened also in political questions, in particular those with the international dimension.

The foreign policy situation revived the students' activities in Ljubljana. It was one of the main reasons for activation and radicalisation of student movement in Ljubljana. It all started on 14 May 1970, when a mass protest was organised against the USA military interventions in Cambodia. ${ }^{11}$ The protest took place in the student campus, but the students also marched through the city centre burning American and Soviet flags, which hung out all around the town because of the world basketball championship. They called out slogans such as "Let's exterminate Pentagon", "To Vietnam with CocaCola", "Vietnam - Czechoslovakia", "Yankee go home", "Peace-Freedom", etc. ${ }^{12}$ They protested against the visit of the American President Nixon to Yugoslavia and against Yugoslavia's too friendly relationship with the Greek military regime. ${ }^{13}$ They were in general very critical to the Yugoslav foreign policy, to individual countries and leaders. In their letters to the Foreign Ministry, they demanded the Yugoslav government to break the contacts with non-democratic regimes in the world. Students reacted against all forms of fascism in the world by criticising the attitude of the Yugoslav authorities towards these phenomena. The Ljubljana student movement was in general - like other movements worldwide - a pacifist one.

Students in Ljubljana paid particular attention to the problems of Slovene minority in Austria and Italy. ${ }^{14}$ As a result of the fascist actions in Trieste and the Italian Foreign Minister Aldo Moro claiming Italy's rights to the former zone B, they organised a protest on 12 December 1970, assembling 8000 people, among whom also the inhabitants of Ljubljana. They called it a national and not a political protest meeting, a "spontaneous political move aiming at the plebiscite unity of Slovene students, youth and other citizens." ${ }^{15}$ In their letters to Tito, Foreign Ministry, and Yugoslav Assembly,

11 Ibid., 83-88

12 Ibid., 86.

13 Ibid., 83, 84.

14 Ibid., 111-20.

15 Ibid., 116, 117. 
they addressed their demands for a different Yugoslav policy towards Slovenes in the neighbouring countries.

In the autumn 1970, the "international « issues were replaced by domestic ones. The student movement in Ljubljana became engaged also in the internal policy. They organised a literary marathon and a "teach inn" at the Faculty of Arts. Arresting and convicting one of the student leaders at the Belgrade University was the motive for their political engagement. The intellectual "elite" from the Faculty of Arts took over the leadership of the student movement.

The Ljubljana student movement obtained a political dimension and became massive in the spring 1971.

In April 1971, the students in Ljubljana moved from the "forum" work to the streets. Students went public and their demands to the authorities went beyond the merely student questions. Student activists understood this as a form of "direct democracy”. Student movement became a part of the town, a part of the urban environment as the student protests moved to the very centre of Ljubljana.

It started with the protest meeting on 14 April 1971, when students assembled on the road which passed along the Faculty of Arts, some other faculties and a high school. With this meeting, around 2000 students wanted to draw the attention of the government and the public to unbearable study conditions. The reason was in fact "ecological". The road passing the faculties was in fact the main transit line for heavy trucks travelling from the West to the East of Europe. Because of the impossible conditions for study (noise and trembling of the houses), students demanded the heavy traffic to be moved out of the city centre. However, at the initiative of more radical student functionaries, this peaceful one-hour meeting turned into a spontaneous march to the city centre, where it was stopped by a cordon of helmeted police. The demonstrations ended quietly after three hours, although some calls were heard for a combat with the police. A poet Milan Jesih was even charged before court for "agitating for revolt and physical violence", when he - under the influence of alcohol - metaphorically called for a more radical student action saying: "Too bad we didn't make the barricades, put our snipers behind them and let them shoot the police straight between their eyes". This was the first court proceeding of the authorities against students. It was followed by two more, which resulted in the radicalisation of the student movement. It became a fight against the repression of the state for expressing political opinion and demanding a more efficient state, which the authorities understood as criticism and opposition.

In late April, there was another hustling between the students and the police, when a group of fifty students protested against the visit of the president of the French Government Chaban-Delmas to Ljubljana; they were expressing support to the French left-wing movement by shouting "Vive le mai 68", "Vive l'idée du mai 68", "Long live the Paris Commune" (it was the 100 anniversary of the Paris Commune), "Down with bourgeoisie" and similar ${ }^{16}$ and they sang the Internationale. These demonstrations were stopped by the police.

16 Ibid., 145. 
The interventions of the police and the National Security Service and the court proceedings that followed provoked a conflict between the students and the state authorities. The repressive measures against the students led to the climax of student movement in Ljubljana, when students occupied for eight days the premises of the Faculty of Arts. The authorities' assessment was that the student movement could eventually become so radical that it would turn to violence. They understood the paroles that hung out on the walls of the Faculty of Arts saying: "Students, it is time for a guerrilla, let us resist authoritarianism, and the rise of capitalism!" as a call for action against the authorities as well as an insult to the political system. What the author of the text had in mind was students' unconventional action; he expressed an opposition to the inflow of foreign capital to the Yugoslav economy in a "leftist" manner, because it was supposed to deny socialism and the self-management system. The police confiscated the poster and initiated criminal proceedings against the author; it also prohibited the public tribune where students wanted to raise the questions of noise, pollution and destruction of the nature as a sign of "hypocritical politics of the society ruled by alienation" ${ }^{17}$; as a consequence, also the student leadership reacted. They demanded that the police dismissed all criminal charges against the students. When receiving no answer from the court with regard to the criminal proceedings against the three students charged with attempts of a violent overturn of the social and state system, physical revolt and hostile propaganda, they decided for the occupation of the Faculty of Arts. On May 1971, students occupied the faculty and turned it into the "working colony". They organised debates, lectures, roundtables. Every morning they raised a red flag on the faculty roof singing the International. Professors and the faculty leadership supported them, as did the students from other faculties. Also the university organisation of the Union of Communists agreed with them, finding out that it was "the best school of self-management democracy and of self-raising the revolutionary awareness" and that "the development of the student movement was basically a very positive process, which is a constituent part of the democratisation of the society", because "the essential characteristic of the ideological and political thinking of the students was their desire to achieve a better, more humane socialism very quickly, over the night." ${ }^{18}$

Apart from the demands which provoked the occupation of the faculty, students also called for an improvement of the situation in the society, for general democratisation, for more clarity in economic and political decisions, etc. ${ }^{19}$ Therefore, the student movement understood the occupation of the faculty as a protest against the authorities' reaction to "certain forms of student movement", which in their opinion betrayed the basic "self-management principles of our society". ${ }^{20}$ In the opinion of students, the reasons for such a reaction lied in the social relations, inefficient economic policy, social disparities (students warned against the "red bourgeoisie"), poor social position

17 Iztok Ilich, “Naša pomlad 1971,” in: Pričevanja, december 1985: študentske pomladi, 88.

18 Baškovič et. al., Študentsko gibanje 68-72, 210, 303.

19 Ibid., 170.

20 Ibid., 201. 
of the university and intellectuals in the society, as well as in "insufficient activity of the Union of Communists." ${ }^{21}$ They saw the occupation as a means of amending the political and economic system and not as a means of change. "The society is free only if it dares to face the truth," was the position of the student movement. In the occupation, they saw "a protest against everything that enslaves and takes away freedom, against alienation; it is a manifestation of our freedom and serious distress". They wrote in the Manifest of the occupied Faculty of Arts: "By fighting for freedom of thought and freedom of science, we do not fight for power". They called for more radical selfmanagement, for its realisation, as this was the goal of all reforms. The student movement supported socialism, but required better relations in the society. It was enshrined in the slogan "for communism against 'communism", and in "Our movement is a fight for socialism." 22 They justified their action by the fact that "nobody and nothing except our own conscious action could assure us socialism". They believed that the party - the Union of Communists - should "become the conscience of the society" and has to "preserve its guerrilla character in its relation to institutions". It was in fact an appeal for the "party" to withdraw from the state authority, from "the Stalinist concept of the party". ${ }^{23}$

The occupation ended after eight days. There was no special reaction to it from the authority. Media did not report much about it, which disturbed the students. The main newspaper "Delo" even tried to discredit them with an article about student demonstrations on the occasion of the visit of Chaban-Delmas, by saying that students called him a fascist. They believed the article caused them political damage and required a corrigendum. In the protests against the manipulations of the media, there are some similarities with the events in Berlin in 1968, when students fought against the Springer press.

The student movement in Ljubljana as a critical political factor thus culminated with the occupation of the Faculty of Arts. After this act, the mass activity of the movement waned. By many supporters leaving, it eventually broke up. Only the hard-line activist leaders with the most radical views remained active. They expressed their views in the magazine Tribuna, which was often confiscated. A group of students which also took part in the occupation of the Faculty of Arts tried to organise a left-wing "student party”, which was to preserve 'the revolutionary air' of the spring 1971. But still, the student movement was on the decline.

In the memories of student leaders, their activities of 1971 got mythical dimensions. They were convinced that their mission was to open the eyes of the people and the authorities. They aspired for being the representatives of the society who wanted a change. But criticism was also heard that "despite their pretentious words, they were just at the beginning, their actions were improvised, insufficient and superficial, only a little or even nothing was in fact achieved and their declarative equalisation with 
proletariat was in fact only a "masturbating" pretentiousness". ${ }^{24}$ One of the more radical student leaders said soon after the climax of the student movement: "My first impression is that we exaggerated. We exaggerated about the significance of our actions. We thought we were so important, but we were only nagging students whom only a few listened and almost none took seriously". 25

\section{$* * *$}

The public opinion poll conducted in 1969 revealed how the public saw the student movements. It was made only a year after the student demonstrations stirred Europe and Yugoslavia in 1968. According to the poll, people considered social issues to be the main reasons for student protests in Slovenia, i.e. poor employment opportunities, low value of the work of experts and their leaving for work abroad, poor material conditions of students and limited opportunities for study: the problem of scholarships. More than a half of the surveyed people were favourably inclined to student protests. Only a small proportion (from 4 to $10 \%$ ) considered student protests an expression of political problems; they believed students protested against the inconsistency of politics, discrepancy between the promises, declarations and practice, little opportunities for self-management at the university and inability of students to have any say within the university system, as well as a protest against bureaucracy and nondemocratic actions of the authorities. A part of the public considered student protests only a replication of protests abroad, thus denying the students being a political subject. There was also a "hostile" position to students, saying that they were doing too well, that they did not know what they wanted, that the society and authorities were too generous to them and that they exploited democracy. Some said that it was not a student movement at all but only an activity of some eccentric individuals. The Slovene public considered protests more as a unique student action than an activity which was thought to awake also other layers of the population. The public opinion did not acknowledge student movement the role of a critical voice against the basic contradictions in the society. ${ }^{26}$ In 1971, when students wanted to "revolutionise" the society, the public opinion was not explored, but it most likely remained basically the same: reserved and "conservative".

The student movement in Ljubljana and elsewhere in the late 1960s and early 1970s could be described as diverse and interesting. If judged by the mark it left on the history, it could also be described as being "much ado about nothing". It is above all a nice memory of its creators on their youth and ideals of that time.

24 Ibid, 222. Mladen Dolar, "Prove yourself alive," Tribuna, No. 1, 10. 10. 1971, 4.

25 Ilich, “Naša pomlad 1971," 179 (Jaša Zlobec).

26 Peter Klinar, "Vzroki študentskih nemirov in protestov," Teorija in praksa: revija za družbena vprašanja 8, No. 3 (1971): 386, 395 . 


\section{Sources and Literature}

\section{Archival Sources:}

- SI AS, Arhiv Republike Slovenije:

- AS 1589, Stenografske beleške sa IX. zajedničke sednice Predsedništva in Izvršnog komitete CK SKJ, održane 9. VI. 1968, 77.

\section{Literature:}

- “Revolucioniranje družbe in universe.” In: Baškovič, Ciril, Pavle Gantar, Marjan Pungartnik and Pavle Zgaga. Študentsko gibanje: 1968-72. Ljubljana: Republiška konferenca ZSMS, Univerzitetna konferenca ZSMS, 1982.

- Ilich, Iztok. "Naša pomlad 1971." In: Pričevanja, december 1985: študentske pomladi, edited by Iztok Ilich, Darko Štrajn, and Jaša L. Zlobec. Ljubljana: Partizanska knjiga, 1986.

- Klinar, Peter. "Vzroki študentskih nemirov in protestov." Teorija in praksa: revija za družbena vprašanja 8, No. 3 (1971): 381-96.

- Pirjevec, Jože. Jugoslavija 1918-1992: nastanek, razvoj ter razpad Karadjordjevićeve in Titove Jugoslavije. Koper: Lipa, 1995.

- Repe, Božo. "Liberalizem" v Sloveniji. Ljubljana: RO ZZB NOV Slovenije, 1992.

- Štrajn, Darko. “Nekoč je bilo študentsko gibanje?." In: Pričevanja, december 1985: študentske pomladi, edited by Iztok Ilich, Darko Štrajn, Jaša L. Zlobec. Ljubljana: Partizanska knjiga, 1986.

- Tribuna. "Prove yourself alive." October 10, 1971.

\section{Printed Sources:}

- Baškovič, Ciril, Pavle Gantar, Marjan Pungartnik and Pavle Zgaga. Študentsko gibanje: 1968-72. Ljubljana: Republiška konferenca ZSMS, Univerzitetna konferenca ZSMS, 1982.

\section{Zdenko Čepič}

\section{THE STUDENT MOVEMENT 1968/1971 IN LJUBLJANA IN WIDER CONTEXT}

\section{SUMMARY}

Mass student movements were a characteristic of the late 1960s throughout the world. In Yugoslavia and in Slovenia, too. The student movement in Europe is closely connected with the year 1968. Not only in European but also in the Yugoslav history, this year has a special significance. The student movement is $\gg$ a specific phenomenon of a relatively mass protest on the world scale. We can speak of the student movement as a historical phenomenon in particular in the late 1960s, when it was an organised 
political activity of students aimed at achieving certain political goals. The student movements - given the lack of any formal connectedness (organisational or substantive) between the students' activities in various countries - were largely political. They emerged as a critical "conscience" of economic and social relations and the contradictions in the society. They had ideological roots in Marxism and had a character of a "new leftist" movement. Common to all students' political activities in the late 1960s was the question against whom and against what their activities were oriented, what were their motives and reasons for action. There were similarities and also great differences between student movements in the world, in Europe and even in Yugoslavia, where it evolved differently in various university centres. It was the same and very different at the same time. The student movement in Yugoslavia and Slovenia arouse from the social and political reality of the 1960s. In Yugoslavia, students advocated socialism, but they wanted to make it better, more humane. Students supported the socialist self-management system, but they required the changes that would make it more efficient, democratic and humane.

The student demonstrations in Belgrade in early June 1968 caused the first serious political uproar. The reason was truly banal: they could not agree who would occupy more sits to watch some show, students or brigadiers. After the fight broke out, the police intervened with force. This led to a student uprising. At first, students had no programme or specific goals. These were only formulated after the fight with the police. Also in Slovenia, in Ljubljana (at that time the only Slovene university) the student movement as a political subject emerged for the first time in 1968. On 6 June 1968 students organised a protest meeting in the student campus, because the management of the campus decided to let student rooms to tourists during the summer, which is why students had to vacate them. At the same time, the management also announced to raise the prices of rents. This led to the beginning of organised students' movement at the Ljubljana University. Although these reasons seem banal, there were in fact deeper motives behind them, with a social connotation. Also the student movement in Slovenia went through different phases, from the "trade unionist" demands stemming from worsening of students' material conditions to political demands. In the following years however, the movement at the Ljubljana University became more radical and also political. It turned into a true student movement in terms of their demands and methods of work. In 1969 and 1970, the student movement in Ljubljana focused their criticism to the foreign policy area and since 1970, they decisively intervened also in political questions, in particular those with the international dimension (Vietnam War, Cambodia, Greek military regime, problems of Slovene minority in Austria and Italy). In the autumn 1970, the »international « issues were replaced by domestic ones. The student movement in Ljubljana became engaged also in the internal policy. The Ljubljana student movement obtained a political dimension and became massive in the spring 1971. The student movement in Ljubljana was thus on the one side an expression of anti-capitalist views, and on the other side a criticism of communist power in Yugoslavia. Students in fact fought for communism against "communism". 
In April 1971, the students in Ljubljana moved from the "forum" work to the streets. It started with the protest meeting on 14 April 1971, when students assembled on the road which passed along the Faculty of Arts; around 2000 students wanted to draw the attention of the government and the public to unbearable study conditions. The reason was in fact "ecological". Road passing the faculties was in fact the main transit line for heavy trucks travelling from the West to the East of Europe. This peaceful one-hour meeting turned into a spontaneous march to the city centre, where it was stopped by a cordon of helmeted police. The demonstrations ended quietly after three hours. The repressive measures against the students led to the climax of student movement in Ljubljana, when students occupied for eight days the premises of the Faculty of Arts. The authorities' assessment was that the student movement could eventually become so radical that it would turn to violence. On May 1971, students occupied the faculty and turned it into the "working colony". They organised debates, lectures, roundtables. Every morning they raised a red flag on the faculty roof singing the International. Professors and the faculty leadership supported them, as did the students from other faculties. Apart from the demands which provoked the occupation of the faculty, students also called for an improvement of the situation in the society, for general democratisation, for more clarity in economic and political decisions, etc. The student movement supported socialism, but required better relations in the society. The occupation ended after eight days. There was no special reaction to it from the authority. The student movement in Ljubljana as a critical political factor thus culminated with the occupation of the Faculty of Arts. After this act, the mass activity of the movement waned.

\section{Zdenko Čepič}

\section{ŠTUDENTSKO GIBANJE V LJUBLJANI 1968/1971 V ŠIRŠEM KONTEKSTU}

\section{POVZETEK}

Študentsko gibanje je specifični fenomen svetovnega značaja. O študentskem gibanju kot zgodovinskem pojavu je moč govoriti zlasti ob koncu šestdesetih let 20 . stoletja, ko je šlo za organizirano politično dejavnost študentov po vsem svetu, ki so želeli doseči določene politične cilje. Študentsko gibanje je bilo predvsem politično usmerjeno, čeprav ni imelo neke formalne organizacijske niti vsebinske povezave med študenti in njihovo dejavnostjo v posameznih državah. Nastalo je kot kritična »vest《 ekonomskih in iz njih izhajajočih socialnih razmerij in protislovij takratne družbe $\mathrm{v}$ različnih državah. Ideološko se je naslanjalo na marksizem in je imelo značaj t. i. novolevičarstva. V Jugoslaviji so poudarjeno zagovarjali socializem in ga želeli napraviti 
boljšega, bolj človeškega. Skupna točka politične dejavnosti študentov ob koncu šestdesetih let je bilo vprašanje, proti komu in proti čemu je bila usmerjena ta dejavnost, kakšni so bili vzroki in kakšni povodi. Med študentskim gibanjem po svetu, v Evropi in v Jugoslaviji, kjer se je po različnih univerzitetnih središčih razvijalo različno, so obstajale nekatere podobnosti, pa tudi velike razlike. Bilo je enako in hkrati zelo različno. Študentsko gibanje v Jugoslaviji in v Sloveniji je izhajalo iz družbenih in političnih razmer, ki so opredeljevale jugoslovansko državo v šestdesetih letih.

Študentsko gibanje v Evropi je ozko povezano z letom 1968. To leto ima v evropski in tudi $v$ jugoslovanski zgodovini posebno mesto in pomen. Bilo je $v$ mnogočem prelomno leto. Študentske demonstracije v Beogradu v začetku junija so povzročile v Jugoslaviji v letu 1968 prvi resni politični pretres. Študenti so bili sicer za politični sistem socialističnega samoupravljanja, vendar so zahtevali spremembe, ki bi le-tega napravil bolj učinkovitega, bolj demokratičnega in bolj humanega. Delovanje študentskega gibanja $\mathrm{v}$ Ljubljani je bilo na eni strani izraz protikapitalističnega pogleda študentov, na drugi pa kritika komunističnih oblasti v Jugoslaviji. Borili so se za komunizem proti $\gg$ komunizmu $\ll$.

Po svetu (večinoma v Evropi) so študentski protesti večinoma izbruhnili v letu 1968. V Beogradu v začetku junija 1968. Tam so izbruhnili zaradi resnično banalnega povoda: kdo bo zasedel več mest $\mathrm{v}$ dvorani na neki zabavni prireditvi, ali študenti ali brigadirji. Po prerivanju in pretepu med njimi je s silo nastopila policija. Njen nastop je povzročil študentske nemire. V Sloveniji (na ljubljanski, tedaj še edini slovenski univerzi) je študentsko gibanje kot politični subjekt tudi nastopilo v letu 1968 . V študentskem naselju so študenti 6. junija 1968 pripravili zborovanje, ker je vodstvo študentskih domov sklenilo čez poletje oddati študentske sobe turistom, zato naj bi jih študentje izpraznili. Hkrati pa so napovedali podražitev najemnin za posteljo v študentskem naselju. To oboje je sprožilo začetek organiziranega študentskega gibanja na ljubljanski univerzi. Povod zanj je bil na videz banalen, vzroki pa so bili globlji in so bili socialno obarvani.

Za študentsko gibanje v Sloveniji so tako tudi značilne stopnje razvoja, od »sindikalističnih « zahtev (imenovane tudi »menzaške « zahteve), ki so izhajale iz slabšanja materialnih pogojev študentov, do politizacije. V naslednjih letih se je študentsko gibanje na ljubljanski univerzi radikaliziralo in je postalo bolj politično. Postalo je pravo študentsko gibanje, ki se je kazalo kot tako po vsebini in načinih delovanja. Študentsko gibanje v Ljubljani se je v letu 1969 in 1970 kritično usmerilo v zunanjepolitično dogajanje. Od spomladi 1970 so študentje bolj odločno posegli v politična dogajanja, zlasti tista, povezana z mednarodnim dogajanjem (vojna v Vietnamu, vojna v Kambodži, proti grški vojaški hunti, problemi slovenske manjšine v Avstriji in v Italiji). Jeseni 1970 je »internacionalno « problematiko začela zamenjavati domača. Študentsko gibanje v Ljubljani se je začelo ukvarjati tudi z notranjo politiko. Zares pa je politično vsebino in množičnost dobilo ljubljansko študentsko gibanje spomladi 1971, ko je doseglo vrhunec svojega poslanstva. Aprila 1971 je študentsko gibanje v Ljubljani prešlo iz »forumskega « dela na ulico. Začelo se je s protestnim shodom 14. aprila 1971 na 
cesti, ob kateri je Filozofska fakulteta in še nekaj drugih fakultet ter srednja šola. S tem protestnim shodom, ki se ga je udeležilo nad 2000 študentov, so želeli opozoriti oblasti in javnost na slabe študijske pogoje. Vzrok je bil »ekološki<. Po tej cesti, ki je dejansko v centru mesta, je potekal tranzitni promet težkih tovornjakov iz Zahoda na Vzhod Evrope. Študenti so zaradi nemogočih razmer za študij (hrup in tresenje hiš) zahtevali preusmeritev prometa ven iz mestnega središča. Sicer miren enourni protestni shod se je na poziv bolj 'radikalnih' študentskih funkcionarjev spremenil v spontan pohod proti mestnemu centru, kjer jih je pričakal kordon policije $\mathrm{v}$ čeladah. Zborovanje je preraslo $\mathrm{v}$ demonstracijo, ki se je po treh urah mirno končala, čeprav je bilo slišati tudi pozive $k$ spopadu s policijo. Konflikt med študentskim gibanjem in državnimi oblastmi pa so sprožili posegi policije oziroma Službe državne varnosti in sodni postopki proti študentom, ki so izražali svoje mnenje. Oblasti so namreč ocenile, da želi študentsko gibanje svoje delovanje radikalizirati do te mere, da bo začelo nastopati s silo. Povod za vrhunec dejavnosti študentskega gibanja v Ljubljani, ko so študenti za osem dni zasedli Filozofsko fakulteto, so bili represivni ukrepi proti študentom. 26. maja 1971 so študentje zasedli fakulteto in jo spremenili $v>$ delovni kolonijo «. Organizirali so pogovore, predavanja, okrogle mize. Vsako jutro so ob petju Internacionale na strehi fakultete dvignili rdečo zastavo. Podprli so jih profesorji, vodstvo univerze, z njimi so solidarizirali tudi študentje drugih fakultet. Študentske zahteve, poleg tistih, ki so bile povod za zasedbo fakultete, so zadevale urejanje razmer $\mathrm{v}$ državi in družbi (obča demokratizacija), več jasnosti pri gospodarskih in političnih odločitvah ipd. Študentsko gibanje je bilo namreč socialistično naravnano, želeli pa so bolj urejene odnose v družbi. Zasedba se je končala po osmih dneh. Neke posebne reakcije proti študentom s strani oblasti ni bilo. $Z$ zasedbo Filozofske fakultete je študentsko gibanje v Ljubljani kot kritični politični dejavnik doseglo svojo najvišjo točko. Po koncu zasedbe Filozofske fakultete pa se je aktivnost študentskega gibanja, ki je bilo ob manifestacijah, demonstracijah in drugih množičnih prireditvah množično, nehala. Doživelo je hiter osip in razpad. 